\title{
Comparative Analysis of Radon Accumulation in Public Buildings of Different Class on the Example of Several Sogd Region Cities of Tajikistan
}

\author{
Ulmas Mirsaidov ${ }^{1, ~ *}$, Kholmurod Maripovich Nazarov ${ }^{1}$, Manizha Mahkamovna Makhmudova ${ }^{2}$, \\ Zhakhon Abdurakhmonovich Misratov ${ }^{1}$, Komiljon Abdulmalikovich Ermatov', \\ Matin Zafarjonovich Akhmedov ${ }^{1}$ \\ ${ }^{1}$ Nuclear and Radiation Safety Agency, National Academy of Sciences of Tajikistan, Dushanbe, Republic of Tajikistan \\ ${ }^{2}$ Department of Paediatrics, Avicenna Tajik State Medical University, Dushanbe, Republic of Tajikistan
}

Email address:

ulmas2005@mail.ru (U. Mirsaidov)

${ }^{*}$ Corresponding author

\section{To cite this article:}

Ulmas Mirsaidov, Kholmurod Maripovich Nazarov, Manizha Mahkamovna Makhmudova, Zhakhon Abdurakhmonovich Misratov, Komiljon Abdulmalikovich Ermatov, Matin Zafarjonovich Akhmedov. Comparative Analysis of Radon Accumulation in Public Buildings of Different Class on the Example of Several Sogd Region Cities of Tajikistan. Journal of Health and Environmental Research.

Vol. 7, No. 3, 2021, pp. 122-125. doi: 10.11648/j.jher.20210703.11

Received: June 7, 2021; Accepted: June 26, 2021; Published: July 13, 2021

\begin{abstract}
The article presents data and a comparative analysis of the accumulation of radon in public buildings (preschool, school and medical institutions) located near radioactive tailings, deployed in certain regions of Northern Tajikistan (Istiklol, Buston). Most of the preschool and school educational institutions buildings in Istiklol are two-storey and according to the type of building materials - brick, concrete and stone. It has been revealed that the average value of radon volumetric activity in indoor air in public buildings located in Istiklol city (formerly Taboshar) reaches up to $175 \mathrm{~Bq} / \mathrm{m}^{3}$ and in Buston city (formerly Chkalovsk) to $26 \mathrm{~Bq} / \mathrm{m}^{3}$. The values of radon equivalent equilibrium volumetric activity in indoor air at investigated objects are in the range of $10-330 \mathrm{~Bq} / \mathrm{m}^{3}$ in Istiklol and $8-19 \mathrm{~Bq} / \mathrm{m}^{3}$ in Buston cities. The range of the annual effective dose is from $0.3 \mathrm{mSv}$ to $7.1 \mathrm{mSv}$. Toron has been measured in selected public buildings (schools, kindergartens and hospitals) in Istiklol city and its levels have been established between 20 and $160 \mathrm{~Bq} / \mathrm{m}^{3}$. Indoor gamma dose values measured in schools and kindergartens fixed in the range of $0.1-1.3 \mathrm{mGy} / \mathrm{h}$ and the lowest reading determined less than $0.2 \mathrm{mGy} / \mathrm{h}$. It has been discovered that building materials are the main source for radon intake. But the geology of the region also plays an important role. The data obtained from radon monitoring will be used in preventive measures to protect children from the effects of a radioactive factor. It is noted that the issue of protecting future generation from the harmful effects of ionizing radiation requires a comprehensive study and assessment. For preventive purposes, it is necessary to recommend mandatory periodic ventilation of preschool and school institutions.
\end{abstract}

Keywords: Radonometer, Radon, Monitoring, Detectors, Dose, Activity, Irradiation, School, Kindergarten

\section{Introduction}

\subsection{Issue Relevance}

The radioactive gas radon gives about half of the radiation dose that each person receives from natural radionuclides annually. Preschool and school institutions are the second most important place after housing, where exposure to radon is possible [1].

Radon situation assessment on the territory of northern Tajikistan [2-7] indicates that the uranium legacy sites are the main sources for radon intake into the air. Especially radioactive tailing dumps, located in Istiklol city (factories of poor ores) and B. Gafurov region (Digmay tailing dump), which do not have the necessary protection arrangements to restrict their impact to the environment [8-13]. The places of 
deployment, in many cases, are located near settlements.

\subsection{Research Objective}

The objective of current research is to carry out a comparative analysis of radon accumulation in public buildings of various classes on the example of several cities of the Sogd region of Tajikistan.

\subsection{Research Objects}

The objects of research are schools, kindergartens and medical buildings in Istiklol and Buston cities, Goziyon settlement and B. Gafurov district, which are located close to radioactive tailing dumps, and these dumps are the legacy sites from the former Soviet uranium industry.

\subsection{Study Subject}

The subject of the study is the experimental determination of radon concentration in premises of medical and preschool institutions and schools of the above-mentioned settlements.

\section{Material and Research Methods}

An integral method for radon VA measurement using track detectors and a radon radiometer PPA-01M-03 [14] has been used as a measurement tool.

Indoor radon VA measurements have been carried out during the summer season. Instant radon measurements have been used as a preliminary screening for radon, while accurate measurements should be based on long-term measurements over a long period of time (298 days) using solid state nuclear trackers such as SSNTD.

The radioactive equilibrium coefficient $F_{R n}$ equal to 0.4 is used to convert the radon VA into the equivalent equilibrium volumetric activity (EEVA) of radon $[15,16]$.

\section{Research Results and Discourse}

In total, 8 educational institutions located in different areas of Istiklol city have been investigated. Most of preschool and school educational institutions buildings in Istiklol city are two-storey and the type of building materials are mostly brick, concrete and stone. The measurements have been conducted on the first floors; the duration of one measurement was 25 minutes. The measurements were carried out in the premises of the permanent residence of children - gyms, playrooms and bedrooms. The measurement results are summarized in Table 1.

Table 1. Radon VA values in air of preschool, school and other educational institutions buildings at Istiklol and Buston cities.

\begin{tabular}{|c|c|c|c|c|}
\hline No. & Institution, address & Construction materials & Radon VA, Bq/m $\mathbf{m}^{3}$ & Radon EEVA, Bq/m $\mathbf{m}^{3}$ \\
\hline \multicolumn{5}{|c|}{ Istiklol city } \\
\hline 1 & School No. 1 & concrete & 43 & 17 \\
\hline 2 & School No. 2 & concrete & 37 & 15 \\
\hline 3 & School No. 3 & brick & 25 & 10 \\
\hline 4 & School No. 4 & brick & 144 & 58 \\
\hline 5 & School No. 5 & stone & 150 & 60 \\
\hline 6 & School No. 6 & brick & 52 & 21 \\
\hline 8 & Vocational technical school & stone & 259 & 104 \\
\hline 9 & Medical center & brick & 826 & 330 \\
\hline \multicolumn{5}{|c|}{ Buston city } \\
\hline 10 & Tajikistan Mining and Metallurgical Institute & brick & 47 & 19 \\
\hline 11 & Buston Presidential School & brick & 20 & 8 \\
\hline 12 & Gymnasium No. 1 & brick & 20 & 8 \\
\hline 13 & School No. 4 & brick & 37 & 15 \\
\hline 16 & Kindergarten No. 13 & brick & 20 & 8 \\
\hline 17 & Kindergarten «Mehrona» & brick & 21 & 8 \\
\hline
\end{tabular}

Radon concentration during instantaneous measurements in schools and kindergartens ranges from $20 \mathrm{~Bq} / \mathrm{m}^{3}$ to $259 \mathrm{~Bq} / \mathrm{m}^{3}$. The average radon concentration value is $75 \mathrm{~Bq} / \mathrm{m}^{3}$ and the annual effective dose ranges from $0.3 \mathrm{mSv}$ to $7.1 \mathrm{mSv}$.

Based on obtained data, it is shown that building materials have a significant effect to indoor radon concentration. Regardless of building materials type (natural, artificial or by-products), they contain variable amounts of naturally occurring radionuclides such as the ${ }^{238} \mathrm{U}$ and ${ }^{232} \mathrm{Th}$ decay chain, ${ }^{40} \mathrm{~K}$, etc. Concrete made of granite, pumice and shale aggregates, has higher radon emission rates. For instance, the radon VA value in the vocational school building, built using stone as a building material is equal to $259 \mathrm{~Bq} / \mathrm{m}^{3}$ and in the school No. 5 building this indicator is equal to $150 \mathrm{~Bq} / \mathrm{m}^{3}$.

Furthermore, in addition to building materials, the site geology plays an important role for gamma radiation activity in the room. For example, high radon concentration (826 $\mathrm{Bq} / \mathrm{m}^{3}$ ) in medical center building (old Taboshar) is explained by the fact that the building was built on a land plot with geological anomaly (increased radon emanation), as well as the lack of ventilation in building basement. These parameters exceed the standard of $200 \mathrm{~Bq} / \mathrm{m}^{3}$ (for old buildings) established in the Radiation Safety Standards of the Republic of Tajikistan (NRB-06 SP 2.6.1.001-06) [17].

The obtained data by the instantaneous method have been compared with the indicators obtained by long-term radon 
concentration measurement using SSNTD type solid-state nuclear track detectors for 298 days in a separate public building at Istiklol city. The comparison showed that the data obtained by the radon instantaneous measurement method, as a rule, is higher than the data obtained by the integral method, which were in the range of $30-830 \mathrm{~Bq} / \mathrm{m}^{3}$. Detailed results presented in Table 2.

Table 2. Radon and thoron concentration in some public buildings premises at Istiklol city.

\begin{tabular}{|c|c|c|c|c|}
\hline Sampling site & ${ }^{222} \mathrm{Rn}, \mathrm{Bq} / \mathbf{m}^{3}$ & ${ }^{220} \mathrm{Rn}, \mathrm{Bq} / \mathrm{m}^{3}$ & $\begin{array}{l}\text { Dose of gamma radiation, } \\
\mathrm{mGy} / \mathrm{hour}\end{array}$ & $\begin{array}{l}\text { Annual effective dose of } \\
\text { radon, } \mathrm{mSv} / \text { year* }\end{array}$ \\
\hline City library & $516 \pm 23$ & $154 \pm 72$ & - & 3,7 \\
\hline Palace of Culture (dance hall) & $275 \pm 17$ & $119 \pm 54$ & 0,19 & 2,0 \\
\hline School No. 4 (Entrance) & $53 \pm 7$ & $21 \pm 23$ & 0,32 & 0,4 \\
\hline Hospital (2nd floor) & $31 \pm 6$ & $17 \pm 18$ & - & 0,2 \\
\hline Medical centre (gynecological office) & $574 \pm 24$ & - & 0,24 & 4,1 \\
\hline Palace of Culture (concert hall) & $59 \pm 8$ & $32 \pm 25$ & 0,17 & 0,4 \\
\hline School No. 4 (chemistry room) & $93 \pm 10$ & - & 0,15 & 0,7 \\
\hline School No. 5 (1st floor) & $88 \pm 9$ & $63 \pm 31$ & 1,26 & 0,6 \\
\hline School No. 5 (teachers room) & $217 \pm 15$ & $88 \pm 48$ & 0,18 & 1,6 \\
\hline School No. 5 (history room) & $42 \pm 6$ & - & 0,18 & 0,3 \\
\hline
\end{tabular}

*For calculating the annual effective dose from radon, 2000 hours per year as an exposure time has been taken into account (for a patient's stay in a hospital, the time of an actual stay has been taken into account).

Thoron has been measured in selected public buildings (schools, kindergartens, hospitals) at Istiklol city and its levels have been established from 20 to $160 \mathrm{~Bq} / \mathrm{m}^{3}$ (Table 2).

High radon and thoron concentration have been noted in the city library $\left({ }^{222} \mathrm{Rn}=516 \pm 23 \mathrm{~Bq} / \mathrm{m}^{3}\right.$ and $\left.{ }^{220} \mathrm{Rn}=154 \pm 72 \mathrm{~Bq} / \mathrm{m}^{3}\right)$, in Palace of Culture dance hall $\left({ }^{222} \mathrm{Rn}=275 \pm 17 \mathrm{~Bq} / \mathrm{m}^{3}\right.$ and ${ }^{220} \mathrm{Rn}=119 \pm 54 \mathrm{~Bq} / \mathrm{m}^{3}$ ), which are located on the first floors of these buildings, erected in 40-50s of the last century using building materials with increased NORM content.

Excess radon $\left({ }^{222} \mathrm{Rn}=217 \pm 23 \quad \mathrm{~Bq} / \mathrm{m}^{3}\right)$ and thoron $\left({ }^{220} \mathrm{Rn}=88 \pm 48 \mathrm{~Bq} / \mathrm{m}^{3}\right)$ concentrations have been also observed in school No. 5 teacher's office (the former mining administration building). This room area is about $20 \mathrm{~m}^{2}$ and it is ventilated poorly in cold weather, unlike other school classrooms. It should be noted that the school No. 5 building, located on a hill near open dumps of "Poor ores factory" and open pit No. 1, is well blown by winds from different directions.

Indoor gamma dose values measured in schools and kindergartens presented in the range $0.1-1.3 \mathrm{mGy} /$ hour, with most readings being less than $0.2 \mathrm{mGy} /$ hour.

Radon concentration range in hospitals, medical centers in Istiklol city has been established from 20 to $2900 \mathrm{~Bq} / \mathrm{m}^{3}$, in three medical centers radon concentration exceeded 1500 $\mathrm{Bq} / \mathrm{m}^{3}$. Gamma radiation dose range presented from 0.12 $\mathrm{mGy} / \mathrm{h}$ to $21 \mathrm{mGy} / \mathrm{h}$, measurements have been carried out in the same rooms. The highest radon concentration values have been observed in basements and on the first floors of buildings.

Indoor air radon ERAA is an important factor for radon hazard to territories and it is considered during buildings design and operation for various purposes. The radon intake into indoor air is regulated by radon presence in underlying surface and in building materials that make up the building structure.

\section{Conclusions}

Based on the experimental data of radon VA measurements in the air in public buildings of Istiklol and Buston cities, it can be argued that the main source for radon intake is building materials. As, the building of the Vocational School built using stone as a building material, the value of radon VA is equal to $259 \mathrm{~Bq} / \mathrm{m}^{3}$, and in the building of school No. 5 with the same building material this figure is equal to $150 \mathrm{~Bq} / \mathrm{m}^{3}$.

A comparative analysis of radon accumulation in public buildings showed that the contribution of radon and its decay daughter products to the average annual effective dose for children exposure in the premises of schools and kindergartens is $0.2-4.1 \mathrm{mSv} /$ year.

In addition to building materials, the geology of the region plays an important role in the indications of radon volume activity in the room. For example, the high concentration of radon $\left(826 \mathrm{~Bq} / \mathrm{m}^{3}\right)$ in the medical center (old Taboshar) is explained by the fact that the building was built on a plot of land with a geological anomaly (increased radon emanation), as well as the lack of ventilation in the basement of the building.

The obtained data from radon monitoring results indicate that the problem protecting future generation from ionizing radiation harmful effects requires a comprehensive study and assessment.

For preventive purposes, it is necessary to recommend mandatory periodic ventilation of preschool and school institutions.

\section{References}

[1] Kendivan, O. D. -S., Kuular, A. T. (2014). Radon volumetric activity in the air of preschool buildings in Kyzyl. News of Omsk University, 2, 76-78 (in Russian).

[2] Lespukh, E., Stegnar, P., Yunusov, M., Tilloboev, H., Zyazev, G., Kayukov, P., Hosseini, A., Strømman, G., Salbu B. (2013). Assessment radiological impact of gamma and radon dose rates at former $U$ mining sites in Tajikistan. Journal of Environmental Radioactivity, 126, 147-155. 
[3] Mirsaidov, U. M., Nazarov, Kh. M., Shosafarova, Sh. G., Makhmudova, M. M. (2020). Radon monitoring in the territory of Northern Tajikistan. Radiation hygiene, 13 (1), 68-73 (in Russian).

[4] Boboev, B. D., Khakimov, N., Ermatov, K. A., Nazarov, Kh. M. (2013). Radon concentration in the air of some residential and work premises Chkalovsk and Kairakkum cities. Reports of the Academy of Sciences of the Republic of Tajikistan, 56 (8), 639-642 (in Russian).

[5] Ermatov, K. A., Boboev, B. D., Nazarov, Kh. M., Salomov J. A (2015). Recommendations for reducing radon concentration in water from springs and wells in the Jabbor Rasulov region. News of the Academy of Sciences of the Republic of Tajikistan, 2 (159), 83-86 (in Russian).

[6] Ermatov, K. A., Nazarov, Kh. M., Muminov, S. V., Bakhronov, S. M., Mirsaidov, I. U. (2017). Radon hazard assessment in territory B. Gafurov district of the Republic of Tajikistan. Reports of the Academy of Sciences of the Republic of Tajikistan, 60 (9), 452-455 (in Russian).

[7] Mirsaidov, I. U., Nazarov, Kh. M., Boboev, B. D., Ermatov, K. A., Adkhamov, A., Akhmedov, M. Z., Bakhronov, S. M. (2017) Radon monitoring in the territory of J. Rasulov district of the Republic of Tajikistan. News of the Academy of Sciences of the Republic of Tajikistan, 1 (166), 88-93 (in Russian).

[8] Ermatov, K. A., Salomov, J. A., Khakimov, N., Nazarov, Kh. M., Rakhmatov, N. N. (2015). Environmental aspects of the uranium tailings rehabilitation in Istiklol city in the Republic of Tajikistan. News of the Academy of Sciences of the Republic of Tajikistan, 2 (159), 87-92 (in Russian).

[9] Nazarov, Kh. M., Boboev, B. D., Ermatov, K. A. (2017). Assessment of the radon hazard on the territory of the Digmay tailing dump. XXI century Technosphere safety, 2 (3), 44-48 (in Russian).

[10] Ermatov, K. A., Nazarov, Kh. M., Salomov, J., Bahronov, S. M.,
Mirsaidov, U. (2018). Former uranium facilities potential radiation hazardassessment for population in Istiklol city, Republic of Tajikistan. Radiation hygiene, 11 (2), 83-90 (in Russian).

[11] Nazarov, Kh. M., Ermatov, K. A., Bakhronov, S. M., Mukhamedova, S. G., Mirsaidov, U. M. (2019). Digmai tailing dump (Tajikistan) potential radiation hazard assessment for population living around it. Radiation hygiene, 12 (1), 115-121 (in Russian).

[12] Nazarov, Kh. M., Boboev, B. D., Ermatov, K. A., Bahronov, S. M., Muminov, S. V. (2018). Radon content in the air of the Spitamen region of the Republic of Tajikistan. Reports of the Academy of Sciences of the Republic of Tajikistan, 61 (3), 293-295 (in Russian).

[13] Nazarov, Kh. M., Boboev, B. D., Ermatov, K. A., Murtazaev, H (2019). The current radiation situation in the JabborRasulov region. Scientific notes of KSU. Series of natural and economic sciences, 1 (48), 68-73 (in Russian).

[14] RRA-01M-03 radon radiometer: Operation manual (2006). 35 (in Russian).

[15] Sources and effects of ionizing radiation. UNSCEAR 2000 report to the General Assembly with scientific annexes. Volume 1: Sources (part 1) (2002). Translation from English, ed. acad. RAMS L. A. Ilyin and prof. S. P. Yarmonenko. M. RADEKON, 308 (in Russian).

[16] Ionizing Radiation Effects (2009). UNSCEAR 2006 Report to the General Assembly with Scientific Annexes. Volume II: Scientific Annexes C, D and E. Annex E: Sources-to-effects assessment for radon in homes and workplaces. New York, United Nations, 142.

[17] Radiation safety standards (NRB-06 SP 2.6.1. 001-06), (2006). Dushanbe, Ministry of Justice of the Republic of Tajikistan, 172 (in Russian). 